\title{
Colonization of subterranean habitats by spiders in Central Europe
}

\author{
Vlastimil Růžička ${ }^{1 *}$, Petr Šmilauer ${ }^{2}$, and Roman Mlejnek ${ }^{3}$ \\ ${ }^{1}$ Institute of Entomology, Biology Centre AS CR, Branišovská 31, 37005 České Budẽjovice, Czech Republic \\ ${ }^{2}$ Faculty of Science, University of South Bohemia, Branišovská 31, 37005 České Budẽjovice, Czech Republic \\ ${ }^{3}$ Caves Administration of the Czech Republic, Svitavská 11/13, 67825 Blansko, Czech Republic
}

\begin{abstract}
Using data from the Czech Republic, we studied the distribution of spiders in soils, crevice systems, scree and caves, i.e. subterranean habitats at depths spanning from $10 \mathrm{~cm}$ to $100 \mathrm{~m}$. In total, we found 161 species. The number of species declines with increasing habitat depth, with a major drop in species richness at the depth of 10 meters. Thirteen species exhibit morphological adaptations to life in subterranean habitats. At depths greater than 10 meters, spider assemblages are almost exclusively composed of troglomorphic species. We propose a hypothesis of evolution of troglomorphisms at spiders during Quaternary climatic cycles.
\end{abstract}

Keywords: $\quad$ superficial and deep subterranean habitats; caves; spiders; troglomorphisms; Quaternary climatic cycle

Received 27 November 2012 ; Revised 9 April 2013; Accepted 12 April 2013

Citation: Růžička V., Šmilauer P. and Mlejnek R., 2013. Colonization of subterranean habitats by spiders in Central Europe. International Journal of Speleology, 42 (2), 133-140. Tampa, FL (USA) ISSN 0392-6672 http://dx.doi.org/10.5038/1827-806X.42.2.5

\section{INTRODUCTION}

A variety of subterranean habitats exists and have been colonized by arthropods (Růžička, 1999; Culver \& Pipan, 2009; Giachino \& Vailati, 2010). According to the space dimensions, we can distinguish on one hand the soil, with interstices of dimensions comparable with body size of arthropods inhabiting the soil, and, on the other hand, all other terrestrial subterranean habitats fashioned by spaces distinctly larger than arthropod body dimensions. According to their depth, we can very roughly distinguish superficial subterranean habitats (usually up to several meters deep, with considerable annual temperature fluctuations) and deep subterranean habitats (usually with very limited or no annual temperature fluctuations). Superficial subterranean habitats are formed in soils, cracks and fissures in rock mantle, in bare and forest scree, in slope sediments, in river terraces, and in crevice systems and cave entrances formed in solid rock. Deep subterranean habitats are represented by fissure network in rock massifs, human-sized caves included.

Many subterranean invertebrates display similar morphologies that have evolved convergent under the similar selective pressures imposed by subterranean environment. Such spiders show the typical morphological changes - reduced pigment and eyes and lengthening of appendages (Culver \& Pipan, 2010). Hotspots of subterranean biodiversity in the Europe, characterized by rich occurrence of highly specialized species, are concentrated in the Dinaric Karst (Culver \& Sket, 2000). In Central Europe, the oscillation of climate during the Quaternary brought about repeated shifting and reconstruction of floras and faunas, cave fauna included. During the first Pleistocene glaciation, the eradication of any preglacial highly specialized terrestrial animals inhabiting caves is likely in the periglacial zone (Holdhaus, 1932). All subsequent glaciations represented the same threat for cave animals. In spite of that, we found spiders adapted to life in caves and other subterranean habitats in Central Europe (Rưžička, 1999).

In this paper we concentrate on spiders occupying subterranean habitats in the Czech Republic. The basic aims of our study were (1) to find in which habitats troglomorphic spiders occur, (2) to find how deep to subterranean spaces they penetrate, and (3) to provide a working hypothesis explaining the evolution of troglomorphic spiders in Central Europe.

\section{MATERIALS AND METHODS}

\section{Study area}

The Czech Republic lies in the temperate zone of Europe. The country has diverse geological and geomorphological 
structures and is rich in both superficial and deep subterranean habitats (Hromas, 2009). During Pleistocene glaciations, the Czech Republic formed a narrow ice-free passage between the Northern European and Alpine areas of glaciation (Ehlers \& Gibbard, 2004). Žák et al. (2004, 2009) reported the finding of cryogenic cave carbonates in Czech, Polish, and Slovak caves, formed in slowly freezing water pools, probably on the surface of cave ice. It documents that caves were frozen in areas where discontinuous permafrost intermittently existed during glaciations.

\section{Subterranean habitats and sampling}

We evaluated material of spiders collected in four subterranean habitats (Fig. 1). We use the depth as a surrogate for the degree of isolation from the surface. "Depth" is characterised as the shortest distance, either horizontal or vertical, from the surface habitats. In subsurface habitats, this means the depth below the surface in which the spiders were collected. In caves, it represents the depth below the surface, or horizontal distance to the cave entrance, whichever is smaller (Novak et al., 2012). We collected spiders in pitfall traps (cans with fixation fluid), usually modified board traps (Ružička, 1982, 1988b). Each such sample represents an assemblage of spiders from one trap left in concrete place usually for one year.

\section{Soils (Fig. 1A)}

We collected spiders in soils in three regions in Eastern Bohemia and Northern Moravia (Laška et al., 2011). Spiders were collected using pitfall traps. In total, we obtained 119 samples from the vertical span of 0.15-1.35 m.

\section{Crevice systems (Fig. 1B)}

We collected spiders in crevice systems formed in sandy marl, limestone, and phonolite in three regions in Central, Eastern, and Northern Bohemia. We were
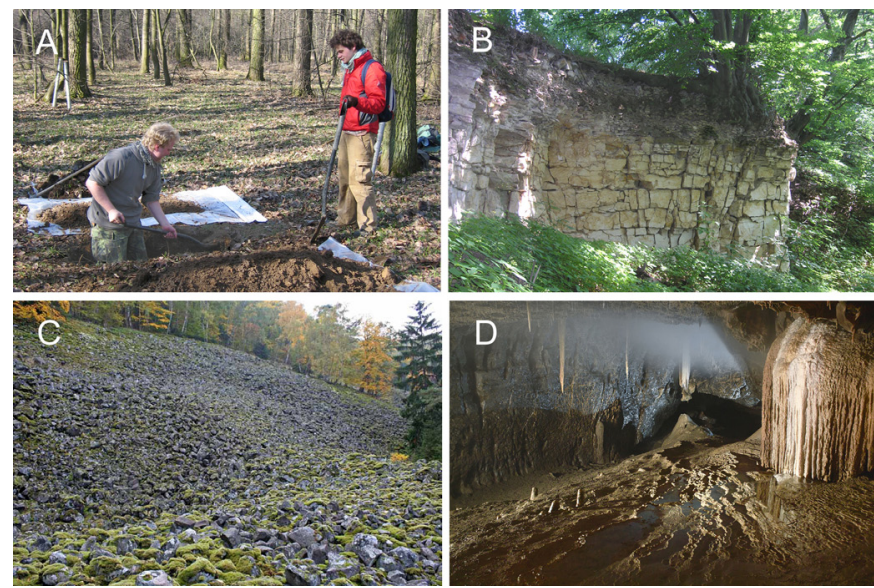

Fig. 1. Examples of habitats studied. a) Soil profile near Horka nad Moravou (Rǔžička et al., 2011; photo by I. H. Tuf) is inhabited by microphthalmous Porrhomma microps $(5-45 \mathrm{~cm})$, and Porrhomma rosenhaueri (35-95 cm); b) crevice system in sandy marle on Džbán plateau near Mutějovice (photo by V. Růžička) is inhabited by depigmented Cicurina cicur, Palliduphantes pallidus, and Centromerus cavernarum; c) scree slope on Kamenec hill near Verneřice-Merboltice (Růžička et al., 2012; photo by L. Jenka) is inhabited by long-legged Wubanoides uralensis lithodytes and Bathyphantes eumenis buchari, as well as microphthalmous Porrhomma rosenhaueri; d) Amatérská cave, Moravian Karst (photo by M. Audy) is inhabited by depigmented Porrhomma convexum, and microphthalmous Porrhomma egeria. unable to dig under the layer of soil at a depth of 2-3 meters to reach crevice system, so using a hammer, a chisel, and a crowbar we penetrated into crevice systems through the side of a quarry wall. Spiders were trapped in pitfall traps. In total, we obtained 10 samples, with sampling depth of $0.35 \mathrm{~m}$ (horizontal distance from the quarry wall).

\section{Scree (Fig. 1C)}

We collected spiders in bare stony accumulations (sloping mass of coarse rock fragments without soil admixture) collected from the whole territory of the Czech Republic. The size of stones ranged from 10 $\mathrm{cm}$ up to $80 \mathrm{~cm}$ (exclusively several meters). The investigated scree are formed by limestone, sandstone, volcanic rocks (basalt, phonolite, andesite), gneiss, conglomerate, quartzite, granite and other kinds of rock (Růžička \& Klimeš, 2005). Spiders were trapped in pitfall traps. In total, we obtained 225 samples from the vertical span of $0.1-6.5 \mathrm{~m}$.

\section{Caves (Fig. 1D)}

We evaluated data from the whole territory of the Czech Republic, from caves formed in limestone (dolomite), sandstone, volcanic rocks (basalt, phonolite), gneiss, sandy marl, and loess. Caves deeper than $20 \mathrm{~m}$ are formed exclusively in limestone. Spiders completing the whole living cycle on concrete place were collected using pitfall traps and hand picking. We do not take into consideration samples from open abysses or caves with open water flow, where spiders living on surface could be transported. In total, we obtained 95 samples varying in depth from $2-100 \mathrm{~m}$.

\section{Spiders and their morphology}

Zacharda (1979), studying the morphological adaptations of mites, distinguished two different classes of adaptations to life in subterranean environment: edaphomorphisms are adaptations to life in soil environment, and troglomorphisms are adaptations to life in all other subsurface habitats. Depigmentation, desclerotization, and the atrophy (even loss) of the eyes are characteristic for both types of adaptations. Legs shorter than in epigean congeners are typical for edaphomorphic species, whereas legs longer than in epigean congeners are typical for troglomorphic species. In harvestmen, depigmentation and changes in leg length are among initial changes, eye size may be the last character affected (Derkarabetian et al., 2010). In spider genus Troglohyphantes, pigmentation is the first to get lost, the next stage is loss of pigment around the eyes, which runs parallel to reduction of eye size (Deeleman-Reinhold, 1978).

We searched for species with published data documenting troglomorphisms/edaphomorphisms among spiders caught. All such populations/taxa are described in relation to conspecific surface population or to closely related surface species. We consider slight changes in leg length and barely noticeable eye diminishing to be initial changes. We designated marked eye reduction, characterized by posterior median eyes interdistance greater than two eye diameters (measured by us), as advanced eye reduction. 
Nomenclature of species is according to Platnick (2012). Dysdera lantosquensis Simon, 1882 sensu Řezáč et al. (2008). We suppose that Porrhomma cambridgei Merrett, 1994 and P. oblitum (Cambridge, 1871) can be conspecific, and for the purpose of this study we designate all specimens as Porrhomma oblitum. We suppose that Porrhomma myops Simon, 1884 and Porrhomma rosenhaueri (Koch, 1872) can be conspecific, and for the purpose of this study we designate all specimens as Porrhomma rosenhaueri.

The spiders were examined and determined under Olympus SZX12 stereomicroscope in 80\% ethanol. The posterior median eyes interdistance were measured with an Olympus BX40 compound microscope fitted with an ocular micrometer. The material for photographing was transferred into a mixture of this ethanol and glycerol $4: 1$. Photographs were taken with an Olympus C-5060 wide zoom digital camera mounted on an Olympus BX40 microscope. The images were montaged using CombineZP image stacking software.

\section{Data analysis}

Counts of individuals for each spider species in each sample, as well as the species richness (measured as the number of spider species occurring in each sample) were log-transformed (using $\ln (x+1)$ formula) before their use in statistical models, to achieve homogeneity of variances in statistical models.

We have summarized the relative changes in composition of spider assemblages across individual sites using the detrended correspondence analysis (DCA) method, with down-weighting of rare spider species (ter Braak \& Šmilauer, 2002, p. 203). The differences in spider assemblages among the four distinguished habitat types was tested and visualized using canonical correspondence analysis (CCA) with a Monte Carlo permutation test of significance (Lepš \& Šmilauer, 2003). Habitat preference of selected spider species (17 species with abundance best predicted by habitat type) was displayed with a pie attribute plot. All multivariate analyses were performed and graph created using Canoco for Windows package version 4.5 (ter Braak \& Šmilauer, 2002).
Change of species richness (number of occurring taxa) with depth was described with a linear model using log-transformed richness as well as log-transformed depth, using F-static based test of model significance. The proportion of troglomorphic taxa in the spider assemblages was predicted using a generalized linear model with an assumed binomial distribution, and this model was tested using likelihood-ratio test based on a test statistic with assumed $\chi^{2}$ distribution under $\mathrm{H}_{0}$. Linear and generalized linear models were fitted using $\mathrm{R}$ package version 2.8 (R Development Core Team, 2008).

\section{RESULTS}

In total, we found 161 spider species across all investigated habitats. Thirteen species exhibit troglomorphisms in all or in some populations. We register them in karst areas, as well as far from karst areas on bedrock of all investigated types. This set of species (Table 1) forms a focal group for our study.

In soils we captured 362 spiders belonging to 35 species. Cicurina cicur, Palliduphantes alutacius, and Harpactea lepida were the most frequent. Porrhomma microps and Porrhomma rosenhaueri are troglomorphic.

In crevices we caught 247 spiders belonging to 32 species. Cicurina cicur, Histopona torpida, and Harpactea lepida were the most frequent ones. Porrhomma microps and Improphantes improbulus are troglomorphic species.

In scree habitats 1362 spiders were collected, belonging to 117 species. Lepthyphantes notabilis, Bathyphantes eumenis buchari, and Rugathodes bellicosus were the most frequent ones. B. e. buchari, Comaroma simoni, Rugathodes bellicosus, Theonoe minutissima, Wubanoides uralensis lithodytes, Improphantes improbulus, Porrhomma egeria, and Porrhomma rosenhaueri are troglomorphic species. The first five were collected exclusively in this habitat.

In caves we captured 917 spiders belonging to 75 species. Porrhomma egeria, Nesticus cellulanus, Meta menardi, and Metellina merianae were the most frequent ones. Porrhomma convexum, Porrhomma oblitum, Porrhomma profundum, Pseudomaroaenigmaticus, Improphantesimprobulus, Porrhomma egeria, Porrhomma microps, and Porrhomma rosenhaueri are troglomorphic species. The first four species were collected exclusively in this habitat.

Table 1. A survey of species exhibiting morphological adaptations to life in subterranean habitats. All of them are depigmented.

\begin{tabular}{|l|l|l|}
\hline Species & Morphology & References \\
\hline Rugathodes bellicosus (Simon, 1873) & body diminishing, leg shortening & Rǔžička (1989, 1998) \\
\hline Theonoe minutissima (O. P.-Cambridge, 1879) & leg elongation & Rǔžička (1998) \\
\hline Comaroma simoni Bertkau, 1889 & eye reduction & Kropf (1998) \\
\hline Bathyphantes eumenis buchari Rǔžička, 1988 & leg elongation & Moritz (1972), Růžička (1998) \\
\hline Improphantes improbulus (Simon, 1929) & leg elongation, eye diminishing & Merrett (1994) \\
\hline Porrhomma oblitum (O. P.-Cambridge, 1871) & leg elongation, advanced eye reduction & Bourne (1977) \\
\hline Porrhomma convexum (Westring, 1851) & eye diminishing & Bourne (1978) \\
\hline Porrhomma egeria Simon, 1884 & advanced eye reduction & Miller \& Obrtel (1975) \\
\hline Porrhomma microps (Roewer, 1931) & advanced eye reduction & Bourne (1977); Růžička et al. (2011) \\
\hline Porrhomma rosenhaueri (L. Koch, 1872) & $\begin{array}{l}\text { advanced eye reduction, leg elongation (scree and } \\
\text { caves), leg shortening (soil) }\end{array}$ & Loksa (1970); Růžička (2009) \\
\hline Porrhomma profundum Dahl, 1939 & advanced eye reduction & Snazell (1978) \\
\hline Pseudomaro aenigmaticus Denis, 1966 & advanced eye reduction & Schikora (2004) \\
\hline Wubanoides uralensis lithodytes Schikora, 2004 & body enlargment, prosoma elongation, leg elongation & \\
\hline
\end{tabular}


We found a great overlap in spider assemblages across the four habitat types (Fig. 2). Seven species were recorded in all four habitats: Centromerus cavernarum, Cicurina cicur, Coelotes terrestris, Harpactea lepida, Histopona torpida, Malthonica silvestris, and Palliduphantes alutacius. Nevertheless, there was a significant difference in spider assemblages among the compared habitats (pseudo- $F=5.3, p=0.001$ ), with habitat type predictor explaining $6 \%$ of the total variation. We have found multiple spider species limited only to one of the recognized habitat types (Fig. 3, the species with symbols overlapping a habitat symbol). Also, the species occurring more frequently in two habitat types preferred either a combination of scree and caves, or a combination of soil and crevices (see Fig. 4).

The number of species in a sample declined with increasing depth, with a major drop in species richness at the depth below 10 meters (Fig 5A). Fitted linear model (with log-transformed species richness as well as the habitat depth) explained $23 \%$ of the richness variation $\left(\mathrm{F}_{1.265}=76.9, \mathrm{p}<0.0001\right)$.

All four types of habitats studied were occupied by some troglomorphic species. The highest number of these species (eight) was recorded in scree and cave habitats. Proportion of troglomorphic taxa in a sample increased with increasing distance from surface habitats (Fig. 5B, fitted generalized linear model explained $25 \%$ of the total variation, $\left.\chi^{2}=98.9, \mathrm{p}<0.0001\right)$. At depths greater than 10 meters, spider assemblage was almost exclusively composed of troglomorphic spider species. However, no studied species was exclusively specialised to deep subterranean habitats.

We arranged troglomorphic species in a sequence based on the maximal depth of occurrence (Fig. 6; Table 2). The species exhibiting initial morphological changes tend to occupy only superficial subterranean habitats (especially scree slopes), and tend to have isolated troglomorphic sub-populations and main

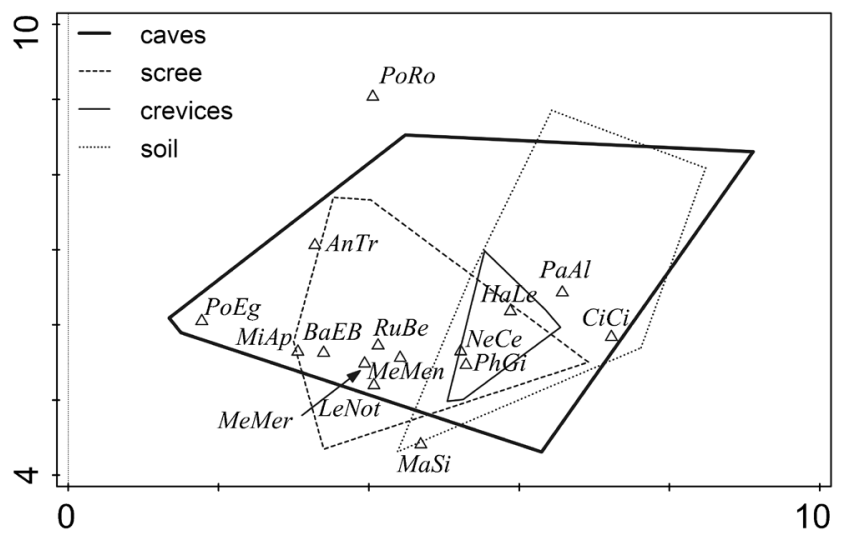

Fig. 2. Ordination diagram with the first two axes of DCA (explaining together $7.4 \%$ of the total variation). The range of site positions for individual habitat types is displayed by enclosing polygonal envelopes (ignoring sites with a single species). Positions of 15 spider species with highest frequency and fit in the ordination plane are shown, using following acronyms: AnTr-Anguliphantes tripartitus, BaEB - Bathyphantes eumenis buchari, CiCi - Cicurina cicur, HaLe - Harpactea lepida, LeNot - Lepthyphantes notabilis, MaSi Malthonica silvestris, MeMen - Meta menardi, MeMer - Metellina merianae, MiAp - Micrargus apertus, $\mathrm{NeCe}$ - Nesticus cellulanus, PaAl - Palliduphantes alutacius, PhGi - Pholcomma gibbum, PoEg - Porrhomma egeria, PoRo - Porrhomma rosenhaueri, RuBe Rugathodes bellicosus.

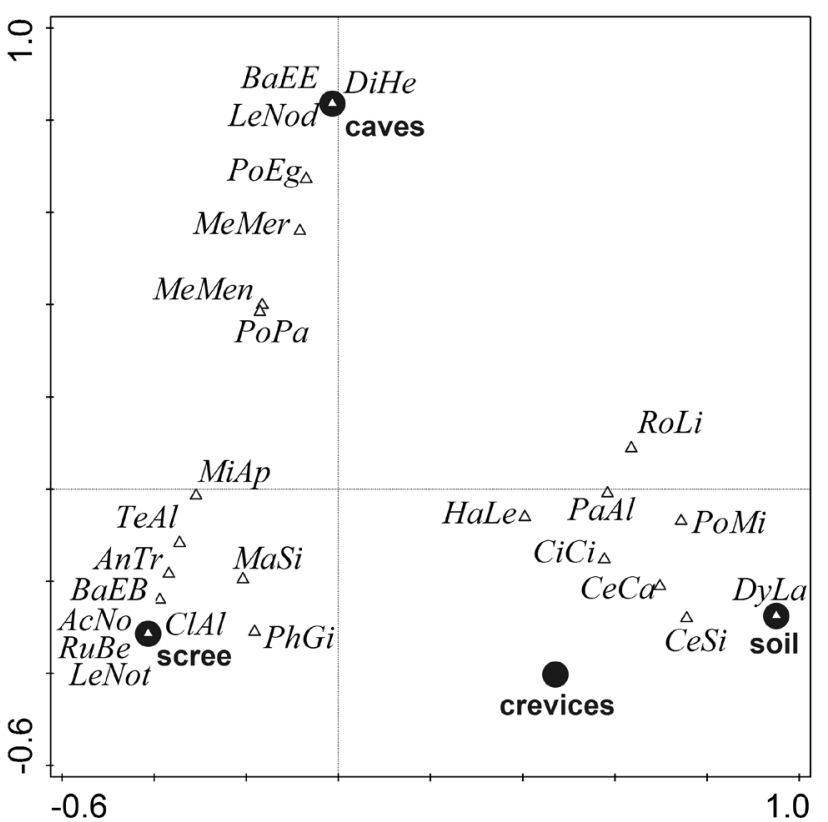

Fig. 3. Ordination diagram with the first two axes of CCA, in which the spider assemblage composition was explained by the habitat type (soil - crevices - scree - caves). Displayed axes summarize $4.8 \%$ of the total variation in spider assemblage data (and $84 \%$ of the total variation explained by habitat type). Positions of 25 species (with highest discrimination among habitat types) are shown, using following acronyms: AcNo - Acantholycosa norvegica, AnTr - Anguliphantes tripartitus,

$\mathrm{BaEB}$ - Bathyphantes eumenis buchari, BaEE - Bathyphantes eumenis eumenis, $\mathrm{CeCa}$ - Centromerus cavernarum, CeSi-Centromerus silvicola, CiCi - Cicurina cicur, CIAl- Clubiona alpicola, DiHeDiplocephalus helleri, DyLa - Dysdera lantosquensis, HaLe - Harpactea lepida, LeNod - Lepthyphantes nodifer, LeNot - Lepthyphantes notabilis, MaSi - Malthonica silvestris, MeMen - Meta menardi, MeMer - Metellina merianae, MiAp - Micrargus apertus, PaAl-Palliduphantes alutacius, PhGi - Pholcomma gibbum, PoEg - Porrhomma egeria, PoMi - Porrhomma microps, PoPa - Porrhomma pallidum, RoLi-Robertus lividus, RuBe - Rugathodes bellicosus, TeAl-Tenuiphantes alacris.

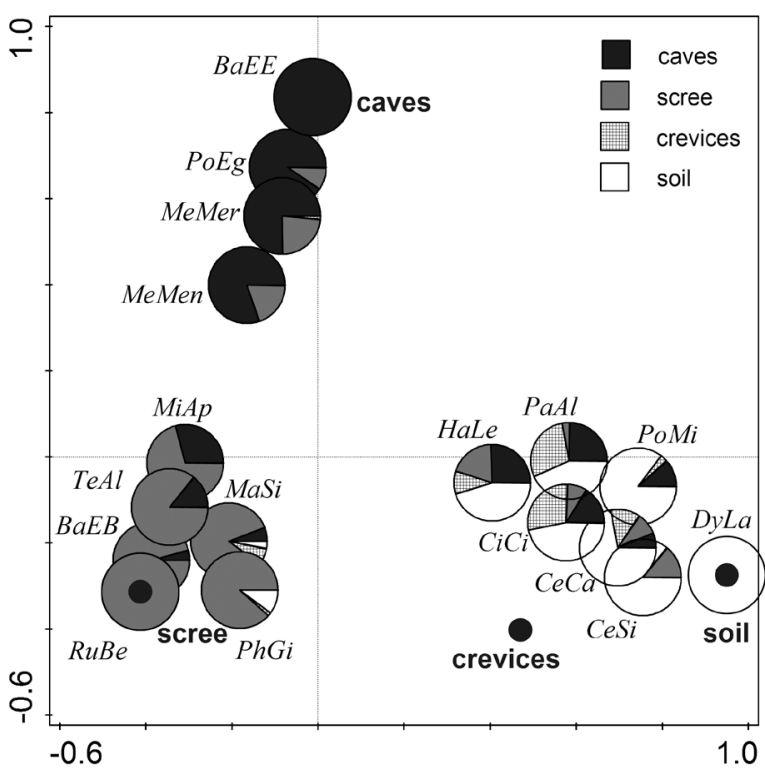

Fig. 4. Pie-attribute plot based on the first two axes of CCA constrained by habitat type (see Fig. 3 legend). Each pie symbol represents one spider species (17 species with highest discrimination among habitat types) and the pie slices represents the percentage of that species' occurrences in individual habitat types. Species acronyms are as follows: BaEB - Bathyphantes eumenis buchari, BaEE - Bathyphantes eumenis eumenis, $\mathrm{CeCa}$ - Centromerus cavernarum, CeSi-Centromerus silvivola, CiCi - Cicurina cicur, DyLa - Dysdera lantosquensis, HaLe - Harpactea lepida, MaSi - Malthonica silvestris, MeMen - Meta menardi, MeMer - Metellina merianae, MiAp - Micrargus apertus, PaAl - Palliduphantes alutacius, PhGi - Pholcomma gibbum, PoEgPorrhomma egeria, PoMi - Porrhomma microps, RuBe - Rugathodes bellicosus, TeAl-Tenuiphantes alacris. 
sub-population inhabiting surface habitats. The species exhibiting advanced eye reduction (Fig. 7) tend to occupy deep subterranean habitats. However, they often occur abundantly also in surface habitats.

\section{DISCUSSION}

We discovered that both superficial and deep subterranean habitats are richly colonized by spiders and numerous species occur in several types of subterranean habitats. This supports the idea of Giachino \& Vailati (2010: 28) that "different subterranean habitats are in fact closely interrelated and form an inseparable continuum."

The high number of troglomorphic spider species found in superficial subterranean habitats documents the importance of these habitats for subterranean evolution of spiders (Růžička, 1999), as the colonizers of subterranean realm must invade first superficial subterranean spaces. It was documented independently also for beetles (Růžička, 1998; Giachino \& Vailati, 2010) and aquatic crustaceans (Culver \& Pipan, 2008; Pipan \& Culver, 2012).

Giachino \& Vailati (2010; see pages 41, 68), studying beetles, found bare scree accumulations as "unsuited for the life of subterranean organisms". But we found bare scree accumulations to be very important for
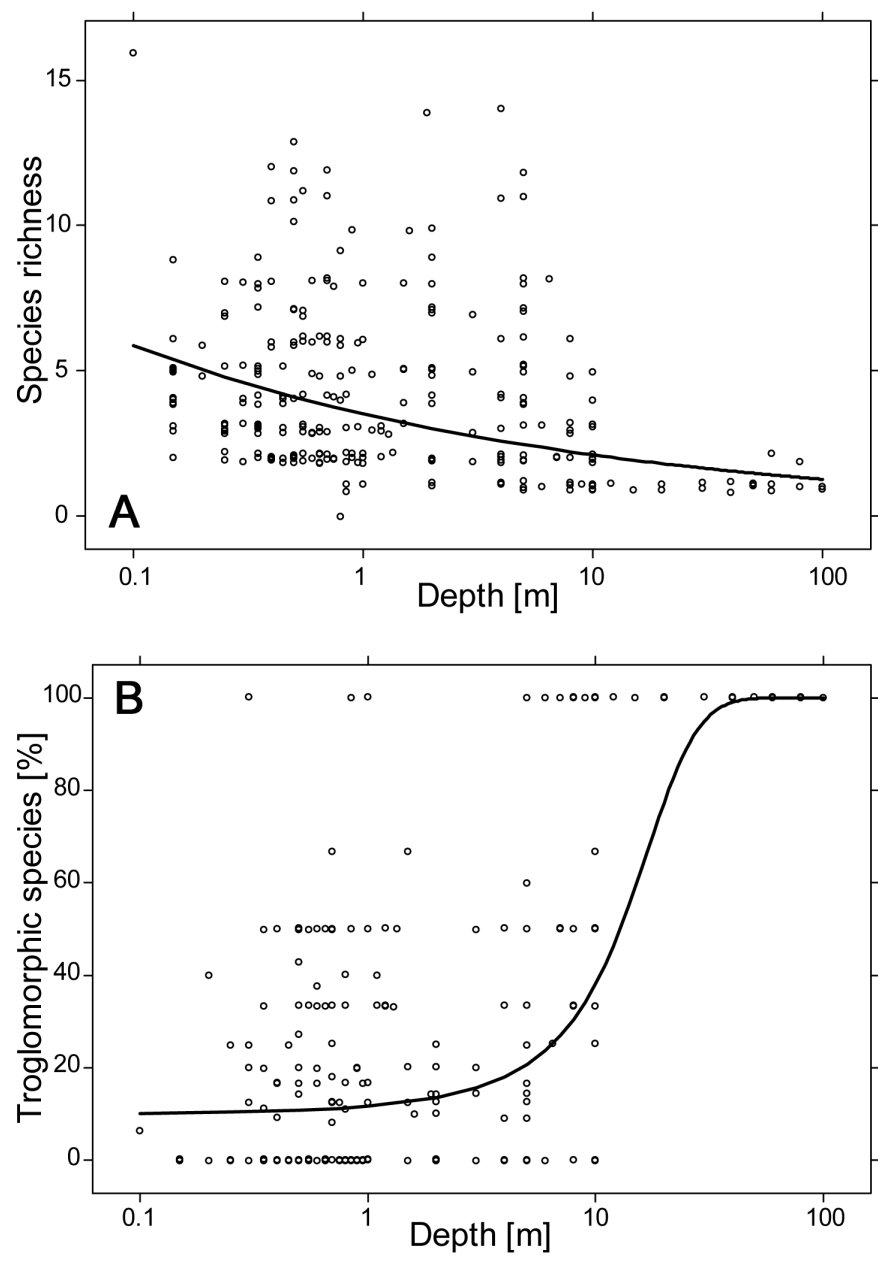

Fig. 5. Change of total species richness a) and the proportion of troglomorphic taxa; b) with the habitat depth.

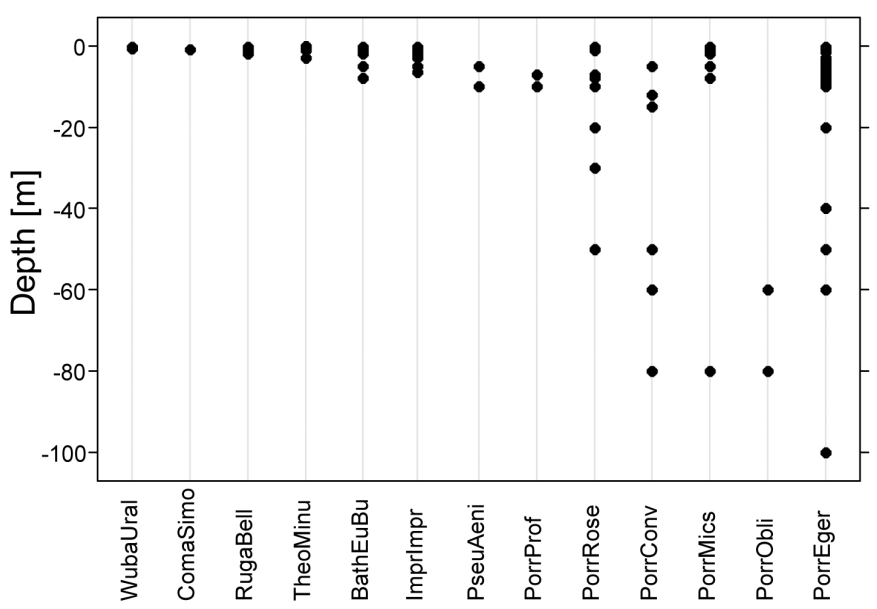

Fig. 6. Distribution of recorded habitat depths for 13 spider species with morphological adaptations to a life in subterranean habitats. The species are sorted according to increasing maximum depth recorded for them in our dataset. Species arcronyms are as follows: WubaUral - Wubanoides uralensis, ComaSimo Comaroma simoni, RugaBell - Rugathodes bellicosus, TheoMinu Theonoe minutissima, BathEuBu - Bathyphantes eumenis buchari, ImprImpr - Improphantes improbulus, PseuAeni - Pseudomaro aenigmaticus, PorrProf - Porrhomma profundum, PorrRose Porrhomma rosenhaueri, PorrConv - Porrhomma convexum, PorrMics - Porrhomma microps, PorrObli - Porrhomma oblitum, PorrEger - Porrhomma egeria.
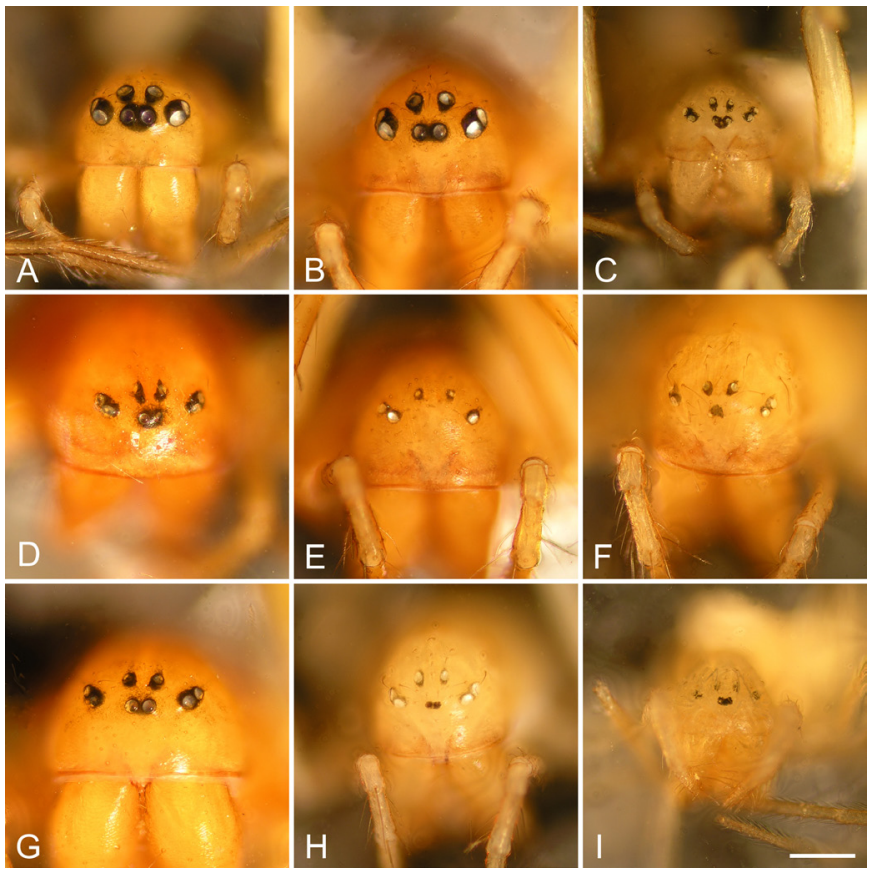

Fig. 7. Face of the spider from the genus Porrhomma, frontal view. a) - P. microphthalmum, basic arrangement and colouring of an eye area in non-troglomorphic surface dweller, České Budějovice, maize field, 380 m a.s.l.; b) - P. convexum, Moravian Karst, Amatérská Cave, $350 \mathrm{~m}$ a.s.I., $60 \mathrm{~m}$ deep (Fig. 1 D); c) - P. oblitum, Karlštejn, forest steppe, tree bark, 310 m a.s.l. (Thaler et al., 2003); d) - $P$. egeria, Krkonoše Mountains, $1180 \mathrm{~m}$ a.s.l., spruce forest; e) - P. egeria, Moravian Karst, Amatérská Cave, 350 m a.s.I., 60 $\mathrm{m}$ deep (Fig. 1 D); f) - P. profundum, Štramberk, Slámova Cave, $410 \mathrm{~m}$ a.s.l., $10 \mathrm{~m}$ deep; g) - P. microps, Horka nad Moravou, lowland forest, $220 \mathrm{~m}$ a.s.l., in leaf litter and in the soil up to the depth of $45 \mathrm{~cm}$ (Fig. 1A); h) - P. rosenhaueri, Verneřice-Merboltice, $350 \mathrm{~m}$ a.s.I., basalt scree (Fig. $1 \mathrm{C}$ ); i) - P. rosenhaueri, Horka nad Moravou, lowland forest, $220 \mathrm{~m}$ a.s.l., $35-95 \mathrm{~cm}$ deep in the soil (Fig. 1A). Scale bar $=0.2 \mathrm{~mm}$. 
Table 2. A set of troglomorphic/edaphomorphic species caught. The presence of specimens with advanced eye reduction (posterior median eyes interdistance > 2.0), usual occurrence in surface habitats in the Czech Republic (Buchar \& Růžička, 2002), and the presence in four habitats studied. Species acronyms are as in Fig. 6.

\begin{tabular}{|c|c|c|c|c|c|c|c|c|c|c|c|c|c|}
\hline Species & 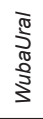 & 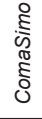 & 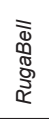 & 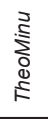 & 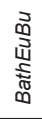 & $\begin{array}{l}\text { 하 } \\
\text { हे }\end{array}$ & 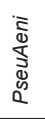 & 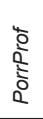 & 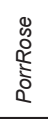 & $\begin{array}{l}\vec{े} \\
0 \\
\vdots \\
0 \\
0\end{array}$ & 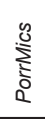 & $\begin{array}{l}\overline{\bar{\partial}} \\
\text { oे } \\
0\end{array}$ & $\begin{array}{l}\bar{\Phi} \\
\text { 心 } \\
\text { ¿ } \\
0\end{array}$ \\
\hline \multicolumn{14}{|c|}{ Advanced eye reduction } \\
\hline \multicolumn{14}{|c|}{ Surface habitats } \\
\hline \multicolumn{14}{|l|}{ Soils } \\
\hline \multicolumn{14}{|l|}{ Crevices } \\
\hline \multicolumn{14}{|l|}{ Scree } \\
\hline Caves & & & & & & & & & & & & & \\
\hline
\end{tabular}

the life and evolution of subterranean spiders, maybe because the spiders, as good climbers, are better adapted for colonization of bare stone and rock surfaces (Rủžička et al., 2010).

Generally, the degree of eye regression increases with phylogenetic age (Culver et al., 1995; Langecker, 2000). If we suppose that the evolution of initial troglomorphisms took place during Holocene (Paquin et al., 2009; Růžička, 2011), the origin of species exhibiting advanced troglomorphisms must have probably occurred earlier.

Blick \& Kreuels (2002) documented numerous records of microphthalmous Pseudomaro aenigmaticus: in caves, in open terrain, and also in aeroplankton in $12 \mathrm{~m}$ height. That documents that some troglomorphic spiders may preserve the ability to balloon, and to disperse. Especially members of the family Linyphiidae are known as good ballooners. This family is particularly well represented in the temperate and cooler regions of the Northern Hemisphere (Jocque \& Dippenaar-Schoeman, 2006) and contains numerous troglomorphic taxa (e.g. in genera Porrhomma, Lepthyphantes, and Troglohyphantes). Porrhomma cavernicola, occurring in Appalachian caves, is an example of "exceptionally widespread troglobite" (Miller 2005).

In Central Europe, Quaternary climatic cycles influenced all natural processes (Ložek, 1976). Interglacial periods are characterized by average annual temperature of $8-12{ }^{\circ} \mathrm{C}$, by precipitation of 700-1000 mm, by development of closed forests, by intensive karst processes, and by flowstone formation in caves. Caves are accessible and could be colonized by spiders, with consequent evolution of troglomorphic characters. Glacial periods, in their maxima, are characterized by average annual temperature between -5 and $-3{ }^{\circ} \mathrm{C}$, by precipitation of $100-200 \mathrm{~mm}$, by development of cold steppe or (at higher altitudes) tundra vegetation, and by ice formation in caves. Terrestrial animals cannot survive in caves filled with ice (Culver \& Pipan, 2010). We assume, that the troglomorphic populations migrated to subsurface and surface habitats. Vertical migrations of cave beetles are well known (Polak, 2012). Following that phenomenon troglomorphisms could have been introduced into populations inhabiting subsurface and surface habitats. Troglomorphic spiders could survived there as they do in present time: such as $P$. microps in leaf litter (Miller \& Obrtel, 1975), such as $P$. oblitum in detritus and under tree bark (Thaler et al., 2003), such as $P$. rosenhaueri in scree habitats (Růžička et al., 2012), such as $P$. convexum or $P$. egeria in various cold and humid habitats, e.g. in mountains. Especially the scree habitats offer a broad scale of microhabitats (Růžička, 1990; Růžička et al., 1995; Zacharda et al., 2007).

Holdhaus (1932) delimited the northern distribution of blind animals occurring exclusively in caves and documented it on very extensive material. The line goes roughly on northern margin of Pyrenees, southern margin of the Alps, and northern margin of Dinarides. In the region of long-term stable climate (below Holdhaus' line), animals might have continuously penetrated in deeper and more isolated spaces and troglomorphisms might have evolved. The contact between troglomorphic and surface populations could have been eliminated (surface ancestor can become extinct or migrate elsewhere) and troglomorphs could have evolved in a new species (principally different from surface ancestor) (Fig. 8A). But what about above Holdhaus' line, in Central Europe?

We hypothesize that troglomorphic populations of spiders in Central Europe repeatedly migrated from caves to subsurface and surface habitats during glaciations. Troglomorphisms were introduced into populations living in these habitats. Therefore, in the present time, advanced troglomorphic characters
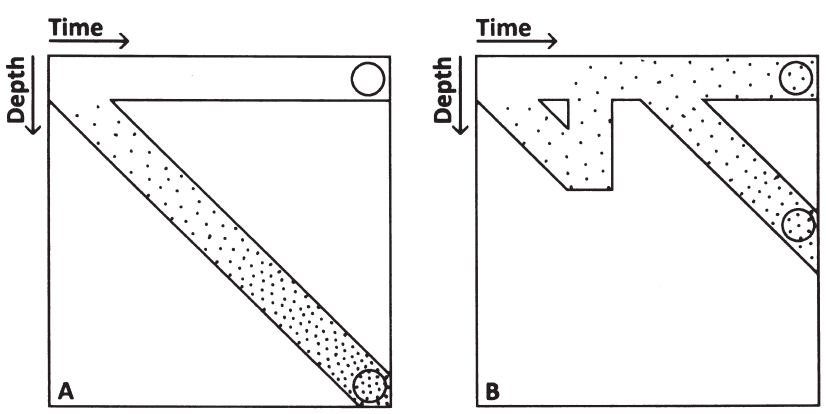

Fig. 8. Supposed scheme for the process of colonization of subterranean spaces and evolution of troglomorphisms (their intensity indicated by increasing dots density) in long term stable climate (A) and during glacial cycles (B). After a certain time period, the (encircled) samples of subterranean and surface population principly differ in stable climate, but are similar after several glacial cycles. 
occur in deep caves as well as in surface habitats far from karst regions (Fig. 8B), and the broad variability of morphological characters complicates their taxonomic evaluation. The research of evolution of troglomorphic spiders in Pleistocene periglacial zone should take into account multiple glaciations.

\section{ACKNOWLEDGEMENTS}

We would like to thank David Culver and Tanja Pipan for their interest and stimulating discussions during their visit of the Czech Republic in July 2011, and Tone Novak and David Culver for substantial improvement of the manuscript. Petr Švácha and Adam Rưžička assisted with spiders photographing and figures preparation. This research was conducted with institutional support RVO:60077344. P.S. contribution was supported by a grant from University of South Bohemia, GAJU 04-142/2010/P.

\section{REFERENCES}

Blick T. \& Kreuels M., 2002 - All known records of Pseudomaro aenigmaticus Denis, 1966. http:// www.theoblick.homepage.t-online.de/Pseudomaro/ Pseudomaro-Info.html

Bourne J.D., 1977 - Contribution a l étude du genre Porrhomma (Areaneae, Linyphiidae). Caractéres morphologiques, biométrie et écologie au niveau des populations de $\mathrm{P}$. convexum (Westring) et $\mathrm{P}$. myops (Simon). Mitteilungen des Schweizerischen entomologischen Gesellschaft, 50: 153-165.

Bourne J.D., 1978 - A contribution to the study of the genus Porrhomma (Araneae: Linyphidae). Notes on a population of $\mathrm{P}$. egeria (Simon) and other cavernicolous species. International Journal of Speleology, 9: 86-96. http://dx.doi.org/10.5038/1827-806X.9.2.1

Buchar J. \& Růžička V., 2002 - Catalogue of spiders of the Czech Republic. Peres, Praha, $351 \mathrm{p}$.

http://arachnology.cz/cas/app_contents/downloads/ bibliography/ARA681.pdf

Culver D.C., Kane T.C. \& Fong D.W., 1995-Adaptation and natural selection in caves. The evolution of Gammarus minus. Harvard University Press, Cambridge, 240 p.

Culver D.C. \& Pipan T., 2008 - Superficial subterranean habitats - gateway to the subterranean realm? Cave and Karst Science, 35: 5-12.

Culver D.C. \& Pipan T., 2009 - The biology of caves and other subtrerranean habitats. Oxford University Press, New York, $254 \mathrm{p}$.

Culver D.C. \& Pipan T., 2010 - Climate, abiotic factors, and the evolution of subterranean life. Acta Carsologica, 39: 577-586.

http://carsologica.zrc-sazu.si/downloads/393/Culver.pdf

Culver D.C. \& Sket B., 2000 - Hotspots of subterranean biodiversity in caves and wells. Journal of Cave and Karst Studies, 62: 11-17.

Deeleman-Reinhold C.L., 1978 - Revision of the cave-dwelling and related spiders of the genus Troglohyphantes Joseph (Linyphiidae), with special reference to the Yugoslav species. Slovenska Akademija Znanosti in Umetnosti, Ljubljana, 220 p.

Derkarabetian S., Steinmann D.B. \& Hedin M., 2010 Repeated and time-correlated morphological convergence in cave-dwelling harvestmen (Opiliones, Laniatores) from montane western North America. PLoS One, 5 (5): e10388. http://dx.doi.org/10.1371/journal.pone.0010388

Ehlers J. \& Gibbard P.L., 2004 - Quarternary Glaciations. Extent and Chronology: Pt. 1. Europe. Elsevier, Den Haag, 475 p.
Giachino P.M. \& Vailati D., 2010 - The Subterranean Environment. Hypogean Life, Concepts and Collecting Techniques. WBA Handbooks, Verona, $132 \mathrm{p}$.

Holdhaus K., 1932 - Die europäische Höhlenfauna in ihren Beziehungen zur Eiszeit. Zoogeographica, Jena, 1: 1-32.

Hromas J. (Ed.), 2009 - Caves. Agency for Nature Conservation and Landscape Protection of the Czech Republic, Praha, 608 p. (in Czech).

Jocqué R. \& Dippenaar-Schoeman A.S., 2006 - Spider families of the world. Royal Museum for Central Africa, Tervuren, $336 \mathrm{p}$.

Kropf C., 1998 - Distribution and geographic variation of Comaroma simonii Bertkau, 1889 (Arachnida, Araneae, Anapidae). In: Ebermann E. (Ed.), Arthropod Biology: Contributions to Morphology, Ecology and Systematics. Wien: ÖAW: 315-331.

Langecker T.G., 2000 - The effects of continuous darkness on cave ecology and cavernicolous evolution. In: Wilkens H., Culver D.C. \& Humphreys W.F. (Eds.), Subterranean Ecosystems. Ecosystems of the World, 30. Amsterdam: Elsevier: 135-157.

Laška V., Kopecký O., Růžička V., Mikula J., Véle A., Šarapatka B. and Tuf I.H., 2011 - Vertical distribution of spiders in soil. Journal of Arachnology, 39: 393-398. http://dx.doi.org/10.1636/P09-75.1

Lepš J. \& Šmilauer P., 2003 - Multivariate analysis of ecological data using Canoco. Cambridge University Press, Cambridge, 269 p.

Loksa I., 1970 - Die Spinnen der „Kölyuk“-Höhlen im Bükkgebirge (Biospeologica Hungarica XXXIII). Annales Universitatis Scientiarum Budapestinensis de Rolando Eötvös nominatae, Sectio Biologica, 12: 269-276.

Ložek V., 1976-Klimaabhängige Zyklen derSedimentation und Bodenbildung während des Quartärs im Lichte malakozoologischer Untersuchungen. Rozpravy Československé akademie věd, Řada matematických a přirodních věd, Praha, 86 (8): 1-97.

Merrett P., 1994 - Porrhomma cambridgei, replacement name for Porrhomma oblongum (O. P.-Cambridge, 1871), revalidated and redescribed from southern England (Araneae: Linyphiidae). Bulletin of the British Arachnological Society, 9: 318-320.

Miller J.A., 2005 - A redescription of Porrhomma cavernicola Keyserling (Araneae: Linyphiidae) with notes on Appalachian troglobites. Journal of Arachnology, 33: 426-438. http://dx.doi.org/10.1636/04-51.1

Miller F. \& Obrtel R., 1975 - Soil surface spiders in a lowland forest. Acta scientiarum naturalium Academiae scientiarum bohemoslovacae - Brno, 9 (4): 1-40.

Moritz M., 1972 - Lepthyphantes improbulus Simon, 1929, eine troglobionte Spinne des Kyffhäusergebirges (Araneae, Linyphiidae). Deutsche Entomologische Zeitschrift, 19: 307-314.

Novak T., Perc M., Lipovšek S. \& Janžekovič F., 2012 Duality of terrestrial subterranean fauna. International Journal of Speleology, 41: 57-64.

http://dx.doi.org/10.5038/1827-806X.41.2.5

Paquin P., Dupérré N., Buckle D.J. \& Lewis J.J., 2009 Oreonetides beattyi, a new troglobitic spider (Araneae: Linyphiidae) from eastern North America, and redescription of Oreonetides flavus. Joural of Cave and Karst Studies, 71: 2-15. http://www.caves.org/pub/ journal/PDF/v71/cave-71-01-2.pdf

Pipan T. \& Culver D.C., 2012 - Convergence and divergence in the subterranean realm: a reassessment. Biological Journal of the Linnean Society, 107: 1-14. http://dx.doi.org/10.1111/j.1095-8312.2012.01964.x

Platnick N.I., 2012 - The World Spider Catalog, version 12.5. American Museum of Natural History, New York. http://research.amnh.org/iz/spiders/catalog 
Polak S., 2012 - Vertical migration of the subterranean beetles as a respond to annual temperature fluctuations. In: Kováč L., Uhrin M., Mock A. \& Luptáčik P. (Eds.), Abstract book of the $21^{\text {th }}$ International Conference on Subterranean Biology. Košice: Pavol Jozef Šafárik Univerzity: $90 \mathrm{p}$.

$\mathrm{R}$ Development Core Team, 2008 - R: A language and environment for statistical computing. $\mathrm{R}$ Foundation for Statistical Computing, Vienna. http://www.r-project.org

Řezáč M., Král J. \& Pekár S., 2007 - The spider genus Dysdera (Araneae, Dysderidae) in central Europe: revision and natural history. Journal of Arachnology, 35: 432-462. http://dx.doi.org/10.1636/H06-38.1

Růžička J., 1998 - Cave and rock debris dwelling species of the Choleva agilis species group from central Europe (Coleoptera, Leiodidae: Cholevinae). In: Giachino P.M. \& Peck S.B. (Eds.), Phylogeny and Evolution of Subterranean and Endogean Cholevidae (=Leiodidae Cholevinae). Torino: Museo Regionale di Scienze Naturali: 261-286.

Růžička V., 1982 - Modifications to improve the efficiency of pitfall traps. Newsletter of the British Arachnological Society, 34: 2-4.

Růžička V., 1988a - Problems of Bathyphantes eumenis and its occurrence in Czechoslovakia (Araneae, Linyphiidae). Věstnîk Československé společnosti zoologické, 52: 149-155.

Růžička V., 1988b - The longtimely exposed rock debris pitfalls. Věstník Československé společnosti zoologické, 52: 238-240.

Růžička V., 1989 - On the lithobionts Lepthyphantes notabilis, Rugathodes bellicosus and on Rugathodes instabilis (Araneae: Linyphiidae, Theridiidae). Acta Entomologica Bohemoslovaca, 86: 432-441.

Růžička V., 1990 - The spiders of stony debris. Acta Zoologica Fennica, 190: 333-337.

Rưžička V., 1996 - Species composition and site distribution of spiders (Araneae) in a gneiss massif in the Dyje river valley. Revue suisse de Zoologie, vol. hors série: 561-569.

Růžička V., 1998 - The subterranean forms of Lepthyphantes improbulus, Theonoe minutissima and Theridion bellicosum (Araneae: Linyphiidae, Theridiidae). In: Selden P.A. (Ed.), Proceedings of the 17th European Colloquium of Arachnology. Burnham Beeches, Bucks: British Arachnological Society: 101-105. http://www.europeanarachnology.org/proceedings/17th/12Ruzicka.pdf

Rủžička V., 1999 - The first steps in subterranean evolution of spiders (Araneae) in Central Europe. Journal of Natural History, 33: 255-265.

Rưžička V., 2009 - The European species of the microphthalmum-group in the genus Porrhomma (Araneae: Linyphiidae). Contributions to Natural History, 12: 1081-1094.

Růžička V., 2011 - Central European habitats inhabited by spiders with disjunctive distributions. Polish Journal of Ecology, 59: 367-380. http://www.pol.j.ecol.cbe-pan.pl
Růžička V. \& Klimeš L., 2005 - Spider (Araneae) communities of scree slopes in the Czech Republic. Journal of Arachnology, 33: 280-289.

http://dx.doi.org/10.1636/04-44.1

Růžička V., Hajer J. \& Zacharda M., 1995 - Arachnid population patterns in underground cavities of a stony debris field (Araneae, Opiliones, Pseudoscorpionidea, Acari: Prostigmata, Rhagidiidae). Pedobiologia, 39: 42-51.

Růžička V., Laška V., Mikula J. \& Tuf I.H., 2011 Morphological adaptations of Porrhomma spiders inhabiting soil. Journal of Arachnology, 39: 355-357. http://dx.doi.org/10.1636/JOACP10-66.1

Růžička V., Mlejnek R. \& Šmilauer P., 2010 - Local diversity versus geographical distribution of arthropods occuring in a sandstone rock labyrinth. Polish Journal of Ecology, 58: 533-544. http://www.pol.j.ecol.cbe-pan.pl Růžička V., Zacharda M., Němcová L., Šmilauer P. \& Nekola J.C., 2012 - Periglacial microclimate in lowaltitude scree slopes supports relict biodiversity. Journal of Natural History, 46 (35-36): 2145-2157. http://dx.doi.org/10.1080/00222933.2012.707248

Schikora H.-B., 2004 - Wubanoides uralensis (Pakhorukov 1981) - Geographic variation, mating behaviour, postembryonic development and description of a new subspecies (Araneae, Linyphiidae). In: Thaler K. (Ed.), Diversität und Biologie von Webspinnen, Skorpionen und anderen Spinnentieren. Denisia, 12. Linz: Biologiezentrum/ Oberösterreichisches Landesmuseum: 271-280.

Snazell R., 1978 - Pseudomaro aenigmaticus Denis, a spider new to Britain (Araneae: Linyphiidae). Bulletin of the British Arachnological Society, 4: 251-253.

Ter Braak C.J.F. \& Šmilauer P., 2002 - Canoco Reference manual and CanoDraw for Windows User's guide: Software for canonical community ordination (version 4.5). Microcomputer Power, Ithaca, NY, USA, 500 p.

Thaler K., Buchar J. \& Kubcová L., 2003 - Neue Funde von zwei Porrhomma-Arten in Zentraleuropa (Araneae, Linyphiidae). Entomologische Nachrichten und Berichte, 46: 173-176.

Zacharda M., 1979 - The evaluation of the morphological characters in Rhagidiidae. In: Rodriguez J.G. (Ed.), Recent Advances in Acarology I. New York: Academic Press: 509-514.

Zacharda M., Gude M. \& Růžička V., 2007 - Thermal regime of three low elevation scree slopes in central Europe. Permafrost and Periglacial Processes, 18: 301-308. http://dx.doi.org/10.1002/ppp.598

Žák K., Hercman H., Orvošvá M. \& Jačová I., 2009 Cryogenic cave carbonates from the Cold Wind Cave, Nizke Tatry Mountains, Slovakia: Extending the age range of cryogenic cave carbonate formation to the Saalian. International Journal of Speleology, 38 (2): 139-152. http://dx.doi.org/10.5038/1827-806X.38.2.5

Žák K., Urban J., Cílek V. \& Hercman H., 2004 Cryogenic cave calcite from several Central European caves: age, carbon and oxygen isotopes and a genetic model. Chemical Geology, 206: 119-136. http://dx.doi.org/10.1016/j.chemgeo.2004.01.012 